\title{
Mammosomatotroph Adenoma
}

National Cancer Institute

\section{Source}

National Cancer Institute. Mammosomatotroph Adenoma. NCI Thesaurus. Code C45928.

A pituitary gland adenoma composed of acidophilic cells that produce both growth hormone and prolactin. Immunohistochemical studies reveal the presence of these two hormones localized in the same cell. 